\title{
Effects of silicate limitation on production of domoic acid, a neurotoxin, by the diatom Pseudo-nitzschia multiseries. II. Continuous culture studies
}

\author{
Youlian $\operatorname{Pan}^{1,3, *}$, D. V. Subba Rao ${ }^{1}$, K. H. Mann ${ }^{1}$, W. K. W. Li ${ }^{2}$, W. G. Harrison ${ }^{2}$ \\ ${ }^{1}$ Habitat Science Division, ${ }^{2}$ Biological Oceanography Section, Department of Fisheries and Oceans, \\ Bedford Institute of Oceanography, PO Box 1006, Dartmouth, Nova Scotia, Canada B2Y 4A2 \\ ${ }^{3}$ Department of Biology, Dalhousie University, Halifax, Nova Scotia, Canada B3H $4 \mathrm{~J} 1$
}

\begin{abstract}
Production of domoic acid (DA) by Pseudo-nitzschia multiseries (Hasle) was studied using continuous cultures with growth rates ranging from 0.06 to $0.67 \mathrm{~d}^{-1}$ At steady states. DA concentrations

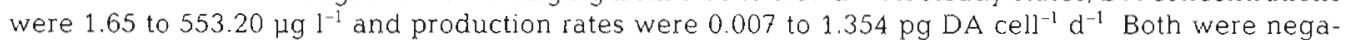
tively correlated with rates of growth and silicate uptake. DA production was studied further by stopping the addition of fresh medium, thus producing batch mode experiments, in some of which silicate was allowed to decline, while in another silicate was increased to $85 \mu \mathrm{M}$. In those where silicate declined, DA production increased by a factor of 3 . The maximum production rate attained was $3.17 \mathrm{pg}$ DA cell ${ }^{-1} \mathrm{~d}^{-1}$ and the highest DA concentration in the culture was $768.5 \mu \mathrm{g} \mathrm{DA} 1^{-1}$, of which $664 \mu \mathrm{g} 1^{-1}$ was in the cells (11.9 pg DA cell ${ }^{-1}$ ). In the experiment where silicate was enriched. DA production was suspended soon after the enrichment, but resumed when silicate in the medium became low. The results suggested differences in kinetics of DA production and growth under different supply rates of sillcate. There appear to be 2 types of conditions associated with DA production. When dissolved silicate is moderately low and there is a decline in overall physlological activity, intrinsic factors probably trigger the formation of a moderate amount of $\mathrm{DA}$. When dissolved silicate is severely limiting, the extrinsic stress leads to considerably enhanced production of DA.
\end{abstract}

KEY WORDS: Pseudo-nitzschia multiseries Domoic acid S Silicate lımitation · Chemostat Contınuous cultures

\section{INTRODUCTION}

The toxigenic blooms of Pseudo-nitzschia multiseries (Hasle) in Cardigan Bay, Prince Edward Island, Canada, in 1987 persisted for 3 mo, causing severe damage to the economics of aquaculture in that region (Addison \& Stewart 1989). During these blooms, silicate concentration in the sea water was low $(<2 \mu \mathrm{M}$; Subba Rao et al. 1988), but the bloom population survived and produced the neurotoxin domoic acid.

In batch culture, the production of domoic acid (DA) by Pseudo-nitzschia multiseries generally occurs in the stationary phase when cell division has stopped

•E-mall:youlian@ac.dal.ca
(Subba Rao et al. 1990, Bates et al. 1991) or when grow th of the culture populations decline due to silicon limitation (Pan 1994). Pan et al. (1996 - this issue) proposed that DA production can be divided into 2 stages: the first coincides with the late exponential phase when growth proceeds slowly, and the second occurs when silicate in the medium is depleted and the culture is in the stationary phase. The rates of DA production during the second stage (13.67 to $30.20 \mathrm{fg} \mathrm{DA} \mathrm{cell}^{-1}$ $\mathrm{d}^{-1}$ ) were an order of magnitude higher than those during the first stage $\left(0.97\right.$ to $4.98 \mathrm{fg}$ DA cell $\left.{ }^{-1} \mathrm{~d}^{-1}\right)$. This implies that (1) toxin production is not necessarily associated with complete cessation of cell division, and (2) this diatom produces more DA when cells are under severe silicate stress. 
In batch culture, population growth rate changes during the course of the culture cycle, as do the physiological stages (Pan et al. 1991). To understand growth rate related physiology, continuous culture study is most suitable since growth rate can be controlled by adjustment of the dilution rate of a steady state. Furthermore, population can be limited by a nutrient at a predetermined level.

In this study, Pseudo-nitzschia multiseries was raised in continuous culture under different silicate concentrations and various rates of population growth to investigate the kinetics of DA production and its relationships with cell chemical composition, nutrient uptake and other metabolic processes. The objective was to understand the relationships between DA production and (1) population growth rates, and (2) levels of silicate limitation.

\section{MATERIALS AND METHODS}

Chemostat system. The continuous culture system (Fig. 1) was maintained at $15( \pm 0.2)^{\circ} \mathrm{C}$ under $290( \pm 50)$ $\mu \mathrm{mol} \mathrm{m} \mathrm{m}^{-2} \mathrm{~s}^{-1}$ continuous cool-white fluorescent light. Fresh medium was added continuously to the culture, which was stirred at about $100 \mathrm{rpm}$ and aerated with sterile air at $30( \pm 10)$ bubbles $\mathrm{min}^{-1}$. The effluent volume was measured daily to confirm the flow (dilution) rate. Six chambers were in operation simultaneously, with one of them, the control, containing no diatoms. The dissolved inorganic silicate (DISi) levels in the control during the experiment (165.39 \pm 9.01 or $55.68 \pm$ $2.84 \mu \mathrm{M}$ ) changed very little and the change was considered negligible.

The culture was monitored daily by measuring in vivo chlorophyll a (chl a) fluorescence. A steady state was defined as a period of 5 d during which the coefficient of variation of the chl a fluorescence was not greater than $5 \%$

Procedures for experiments. A non-axenic culture of Pseudo-nitzschia multiseries (KP-59 strain) was grown and sub-cultured twice in a silicate-reduced $\mathrm{H}$ medium (Humphrey 1963) prepared with Mid-Atlantic sea water for $10 \mathrm{~d}$ before being inoculated into the chemostats.

Three experiments were undertaken. Expts I and II utilized continuous culture, while Expt III was a batch culture resulting from a continuous culture (Expt II) when addition of fresh medium was discontinued. Deionized water (super Q) was added to the aged oceanic water to lower the salinity to $27 \mathrm{psu}$, which is comparable to that of the coastal water of Prince Edward Island, before enriching silicate to $56.2( \pm 3.4)$ $\mu \mathrm{M}$. This medium was made up in either a glass (Expt I) or a polycarbonate carboy (Expt II). The use of a glass carboy, in which the medium was autoclaved, resulted in an additional $100 \mu \mathrm{mol} \mathrm{l}^{-1}$ in silicate concentration. Thus, the resultant silicate concentration in the autoclaved medium was 165.4 ( \pm 9.0$) \mu \mathrm{M}$ in Expt I, but 56.2 $( \pm 3.4) \mu \mathrm{M}$ in Expt II.

A $300 \mathrm{ml}$ sample was collected when a steady state was attained $15 \mathrm{~d}$ after inoculation. Sub-samples $(10 \mathrm{ml})$ were filtered through a $1.0 \mu \mathrm{m}$ Nuclepore filter and analyzed for particulate silicon and phosphorus (Koroleff 1983a, b), and for DA (Pocklington et al. 1990). More sub-samples were filtered through GF/F filters and analyzed for carbon and nitrogen (30 ml), chl a $\left(10 \mathrm{ml}_{\mathrm{i}}\right.$ Strickland \& Parsons 1972), and for adenosine triphosphate (ATP, $30 \mathrm{ml}$; Karl \& Holm-Hansen 1980). Filtrate passed through Nuclepore filters $(<1.0 \mu \mathrm{m})$ was collected for determinations of dissolved silicate, phosphate and DA in the medium. After these samples were taken, the inflow rate of fresh medium was changed and the next steady state was usually attained in $\geq 8 \mathrm{~d}$. A total of 10 such steady state experiments were conducted in 5 of the 6 chambers in Expt I.

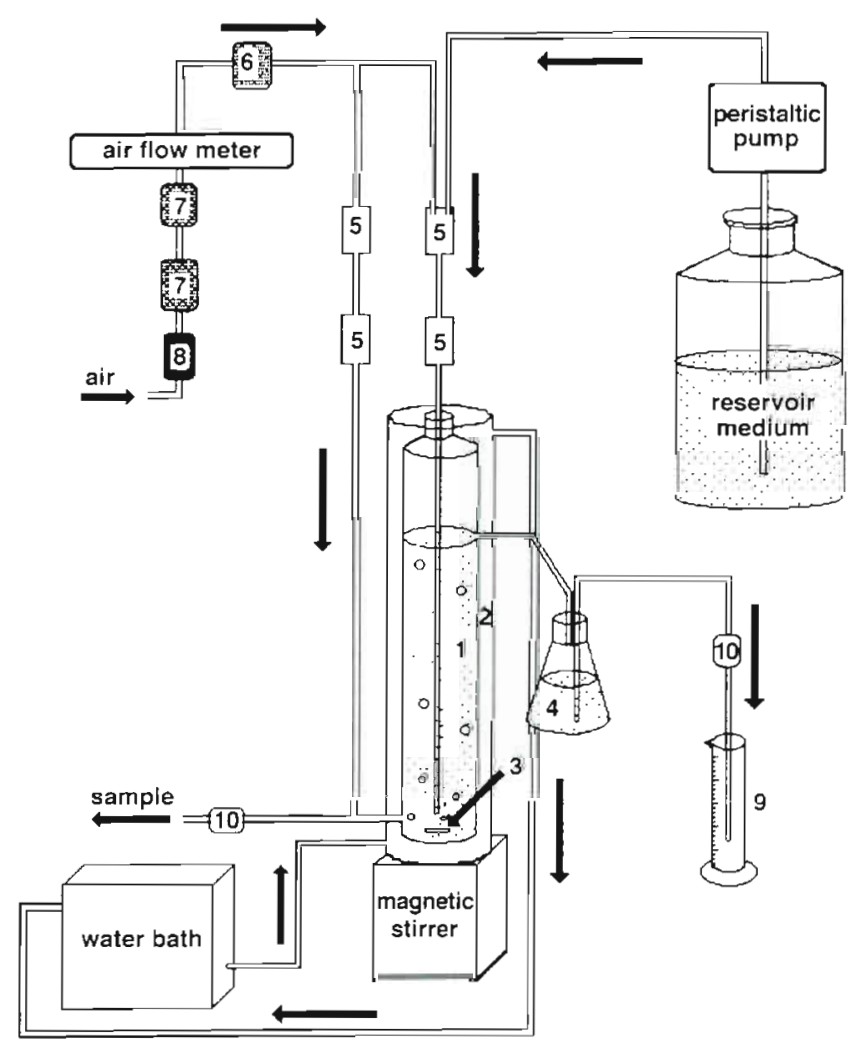

Fig. 1 Schematic display of a chemostat system. (1) Chemostat culture chamber, (2) thermostat water jacket, (3) stir bar, (4) effluent, (5) polycarbonate syringe to avoid culture overflow, (6) sterile air filter $(0.2 \mu \mathrm{m})$, (7) cotton filters, (8) activated charcoal to remove organic compounds in the air, (9) measuring cylinder for effluent measurements, (10) stopcock 
At the end of Expt I, the peristaltic pumps were stopped immediately. All the tubing for supplying fresh medium was changed aseptically and the medium was freshly prepared in plastic carboys. Expt II started 2 d later. The inflow rates were randomly set disregarding the history of the dilution rate. A total of 10 steady state experiments were conducted and subsamples were collected as in Expt I.

In Expt III, the peristaltic pumps were stopped and 3 chambers of the cultures were left as batch culture. The previous dilution rates (D) for these 3 chambers were $0.27,0.10$ and $0.20 \mathrm{~d}^{-1}$ respectively. The silicate concentration in one chamber $\left(D=0.20 \mathrm{~d}^{-1}\right)$ was raised by $85 \mu \mathrm{M}$ at the beginning of the batch mode.

The relationship between DA (production and concentrations) and steady state growth rates in the continuous cultures was parameterized by Eq. 1 and fitted using a computer package, FITALL version 5.1 (FTR Software 1991).

$$
D A=D A_{m} \exp (-\alpha \mu)
$$

where $D A$ is domoic acid (production or concentration) at growth rate $\mu, D A_{\mathrm{m}}$ is the maximum $D A$ at $\mu=$ 0 , and $a$ is the negative initial slope of the exponential curve. Carbon assimilation $\left(P_{\mathrm{m}}^{B}\right)$ used in this study is actually carbon uptake rate normalized to chl $a$.

\section{RESULTS}

Production of DA was negatively correlated with overall physiological activity and varied inversely with growth rates, carbon assimilation and silicate uptake (Fig. 2).

\section{Experiment I, continuous cultures}

Growth rate in the 10 steady states ranged from 0.09 to $0.67 \mathrm{~d}^{-1}$ (Table 1). Cell concentration generally ranged from 72 to $105 \times 10^{6}$ cells $1^{-1}$ except for one steady state at the highest growth rate $\left(0.67 \mathrm{~d}^{-1}\right)$, when the cell concentration was significantly reduced to $48 \times$ $10^{6}$ cells $1^{-1}$. At steady state, DISi concentration in the outflow medium ranged from 2.4 to $106.2 \mu \mathrm{M}$ and increased as the growth rate increased. This suggests that the cultures were not truly silicate limited, except the one at lowest growth rate. All other nutrients were in excess. Therefore, the continuous cultures of Expt I were not truly chemostat.

DA concentrations were related to growth rates by a negative exponential function (Fig. 3; Eq. 1). They were also correlated $(p<0.02)$ negatively with carbon assimilation rate, and with the concentrations of silicate and phosphate in the medium outflow, but positively with ATP concentration in the cells. In addition. DA production was positively correlated $(\mathrm{p}<0.02)$ with the concentrations of particulate carbon and nitrogen.

\section{Experiment II, chemostat cultures}

With lower DISi concentrations $(56.2 \mu \mathrm{M})$ in the fresh inflow medium, on the other hand, DISi in Expt II cultures at steady state remained low and unaffected by the growth rates (Table $1 ;$ Fig. 4), indicating that the steady states were under silicate limitation. However, when growth rates were less than $0.14 \mathrm{~d}^{-1}$, the total dissolved silicon in the culture medium increased as growth rate decreased (Fig. 4), suggesting the dissolution of silicon from cell walls.
Fig. 2. Pseudo-nitzschia multiseries. Relationships between domoic acid (DA) production and other cell metabolic processes
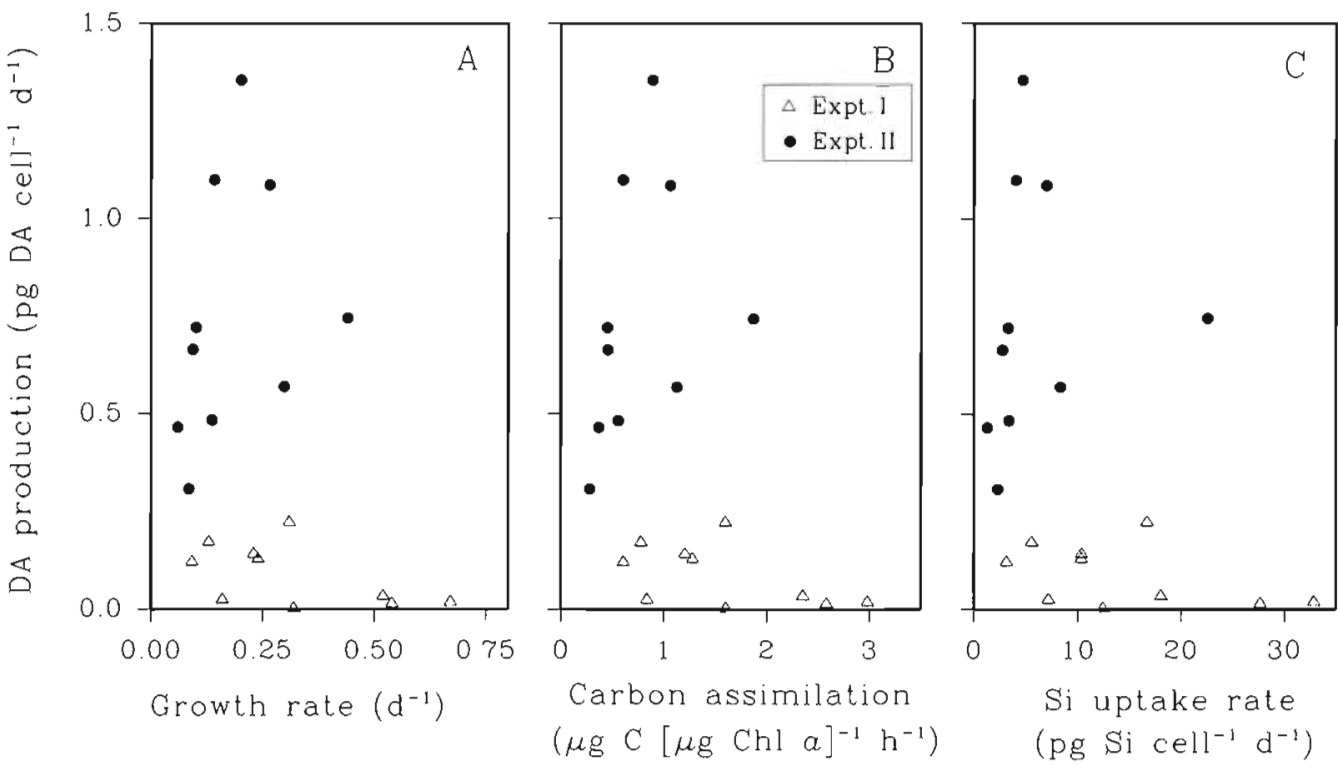
Table 1. Pseudo-nitzschia multiseries. Comparison of means and ranges of measured variables from Expts I and II. DA: domoic acid; $P_{\text {mi }}^{B}$ : carbon assimilation, DISi: dissolved inorganic silicate

\begin{tabular}{|c|c|c|c|c|c|c|c|}
\hline \multirow{2}{*}{ Parameters } & & \multicolumn{3}{|c|}{ Experiment 1} & \multicolumn{3}{|c|}{ Experiment II } \\
\hline & & Mean & Min & Max & Mean & Min & $\operatorname{Max}$ \\
\hline \multicolumn{2}{|l|}{ Growth rate $\left(\mathrm{d}^{-1}\right)$} & 0.322 & 0.092 & 0.669 & 0.183 & 0.061 & 0.441 \\
\hline \multicolumn{2}{|l|}{ Si supply $\left(\mu \mathrm{mol} \mathrm{l} \mathrm{l}^{-1} \mathrm{~d}^{-1}\right)$} & 35.42 & 10.15 & 73.88 & 6.85 & 2.25 & 16.52 \\
\hline \multicolumn{2}{|l|}{ Si uptake (pg cell ${ }^{-1} \mathrm{~d}^{-1}$ ) } & 14.43 & 3.14 & 32.86 & 5.98 & 1.32 & 22.59 \\
\hline \multirow[t]{2}{*}{ DA production } & $\mu g l^{-1} d^{-1}$ & 7.62 & 0.55 & 16.79 & 40.57 & 16.97 & 90.35 \\
\hline & pg cell ${ }^{-1} \mathrm{~d}^{-1}$ & 0.092 & 0.007 & 0.226 & 0.749 & 0.307 & 1.354 \\
\hline \multicolumn{2}{|l|}{ DA in culture $\left(\mu \mathrm{g} \mathrm{I}^{-1}\right)$} & 42.70 & 1.65 & 135.90 & 287.72 & 44.95 & 553.20 \\
\hline \multicolumn{2}{|l|}{ DA in cell (pg cell ${ }^{-1}$ ) } & 0.38 & 0.02 & 1.00 & 2.79 & 1.10 & 5.62 \\
\hline \multicolumn{2}{|l|}{$\mathrm{DA}$ in medium $\left(\mu \mathrm{g} \mathrm{I}^{-1}\right)$} & 9.92 & 0.00 & 36.00 & 129.70 & 2.40 & 399.20 \\
\hline \multicolumn{2}{|l|}{$P_{\mathrm{m}}^{B}\left[\mu g C(\mu \mathrm{gchl} a)^{-1} \mathrm{~h}^{-1}\right]$} & 1.58 & 0.61 & 2.98 & 0.77 & 0.28 & 1.87 \\
\hline \multicolumn{2}{|l|}{$10^{6}$ cell $1^{-1}$} & 80.82 & 48.28 & 104.67 & 54.46 & 26.62 & 71.44 \\
\hline \multicolumn{2}{|l|}{ Chl a $\left(\mu \mathrm{g} \mathrm{l}^{-1}\right)$} & 60.55 & 47.00 & 76.04 & 69.26 & 52.53 & 87.10 \\
\hline \multirow[t]{6}{*}{ Cellular chemicals } & pg chl a cell ${ }^{-1}$ & 0.77 & 0.51 & 1.01 & 1.35 & 0.74 & 2.23 \\
\hline & pg C cell-1 & 94.99 & 76.49 & 124.68 & 139.06 & 102.76 & 227.77 \\
\hline & pg $N$ cell $^{-1}$ & 11.23 & 9.42 & 14.24 & 21.15 & 13.11 & 32.88 \\
\hline & pg Si cell ${ }^{-1}$ & 43.78 & 34.18 & 53.93 & 29.36 & 21.95 & 51.23 \\
\hline & pg P cell-1 & 1.65 & 1.22 & 2.40 & 3.26 & 2.31 & 5.79 \\
\hline & fmol ATP cell ${ }^{-1}$ & 0.109 & 0.012 & 0.226 & 0.156 & 0.045 & 0.330 \\
\hline \multicolumn{2}{|l|}{ DISi $(\mu \mathrm{M})$} & 48.10 & 2.40 & 106.20 & 0.52 & 0.12 & 1.29 \\
\hline \multirow{2}{*}{$\begin{array}{l}\text { Chemical ratios } \\
(\mu \mathrm{g}: \mu \mathrm{g})\end{array}$} & $\mathrm{C}: \mathrm{chl} a$ & 125.59 & 106.76 & 158.42 & 104.79 & 79.61 & 147.97 \\
\hline & Si:chl a & 57.92 & 49.37 & 68.56 & 22.19 & 17.83 & 29.85 \\
\hline \multirow{6}{*}{$\begin{array}{l}\text { Cellular elemental ratios } \\
\text { (atomic) }\end{array}$} & $\mathrm{C}: \mathrm{N}$ & 9.85 & 9.48 & 10.78 & 7.77 & 6.21 & 9.71 \\
\hline & $\mathrm{C}: \mathrm{Si}$ & 5.08 & 3.91 & 5.51 & 11.12 & 8.73 & 13.91 \\
\hline & $\mathrm{N}: \mathrm{Si}$ & 0.52 & 0.39 & 0.60 & 1.48 & 0.94 & 2.00 \\
\hline & $\mathrm{P}: \mathrm{Si}$ & 0.034 & 0.025 & 0.048 & 0.100 & 0.084 & 0.133 \\
\hline & $N: P$ & 15.37 & 11.33 & 18.73 & 14.77 & 10.48 & 19.62 \\
\hline & $C: S i: N: P$ & $151: 30: 15: 1$ & & & $111: 10: 15: 1$ & & \\
\hline
\end{tabular}

Unlike that in Expt I, the concentration of DA in Expt II was not simply an exponentially decreasing function described by Eq. (1). At a very low growth rate, DA concentrations increased to a peak as the growth rate increased to $0.20 \mathrm{~d}^{-1}$. When growth rate increased further, DA decreased as in Expt I (Fig. 4). Generally, DA production was higher in Expt II under silicate limitation than in Expt I (Table 1). At the same growth rates, differences in DISi in the fresh inflow medium resulted in apparent differences in silicate uptake rates, cellular DA and silicon, and DA production (Table 2).

As a result of silicate limitation, cells in Expt II had more chl $a$, carbon, nitrogen, phosphorus and ATP, but less silicon than those in Expt I (Table 1). Unlike the general pattern for most other microalgae, ATP in Pseudo-nitzschia multiseries cells decreased as growth rates increased, but DA production was positively correlated with ATP concentration (Fig. 5).

The mean elemental ratio (atomic) of C:Si:N:P was 151:30:15:1 in Expt I and 111:10:15:1 in Expt II. More silicate entered the cells than nitrogen in Expt I, but the opposite was true in Expt II. N:P ratios (atomic) were consistent between these 2 experiments, although both $\mathrm{N}$ and $\mathrm{P}$ were much lower in the cells from
Expt I (Table 1). Ratios of C:Si, N:Si and P:Si were significantly different $(\mathrm{p}<0.001, \mathrm{n}=10$ ) between these 2 experiments (Fig, 6). In Expt II, the highest DA produc-

Table 2. Pseudo-nitzschia multiseries. Comparison of silicate

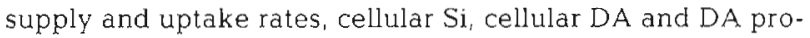
uction from Expts I and II

\begin{tabular}{|c|c|c|}
\hline Parameter & Expt I & Expt II \\
\hline \multicolumn{3}{|l|}{$\mu=0.09 \mathrm{~d}^{-1}$} \\
\hline Si supply rate $\left(\mu \mathrm{mol} \mathrm{l}^{-1} \mathrm{~d}^{-1}\right)$ & 10.14 & 3.52 \\
\hline Si uptake rate (pg Si cell $\left.{ }^{-1} \mathrm{~d}^{-1}\right)$ & 3.14 & 2.78 \\
\hline Cellular Si (pg Si cell-1) & 34.18 & 29.54 \\
\hline Cellular DA (pg DA cell-1) & 0.996 & 2.245 \\
\hline \multirow{2}{*}{$\begin{aligned} \text { DA production } & \mu g \mathrm{DA} \mathrm{l}^{-1} \mathrm{~d}^{-1} \\
& \text { pg DA cell }{ }^{-1} \mathrm{~d}^{-1}\end{aligned}$} & 12.50 & 32.15 \\
\hline & 0.125 & 0.664 \\
\hline \multicolumn{3}{|l|}{$\mu=0.31(0.30) \mathrm{d}^{-1}$} \\
\hline Si supply rate $\left(\mu \mathrm{mol} \mathrm{l}^{-1} \mathrm{~d}^{-1}\right)$ & 34.18 & 11.20 \\
\hline Si uptake rate (pg Si cell ${ }^{-1} \mathrm{~d}^{-1}$ ) & 16.72 & 8.34 \\
\hline Cellular Si (pg Si cell ${ }^{-1}$ ) & 53.93 & 27.91 \\
\hline Cellular DA (pg DA cell ${ }^{-1}$ ) & 0.667 & 1.485 \\
\hline \multirow{2}{*}{$\begin{aligned} \text { DA production } & \mu g \mathrm{DA} \mathrm{l}^{-1} \mathrm{~d}^{-1} \\
& \mathrm{pg} \mathrm{DA} \text { cell } \\
& \end{aligned}$} & 16.79 & 34.83 \\
\hline & 0.226 & 0.568 \\
\hline
\end{tabular}



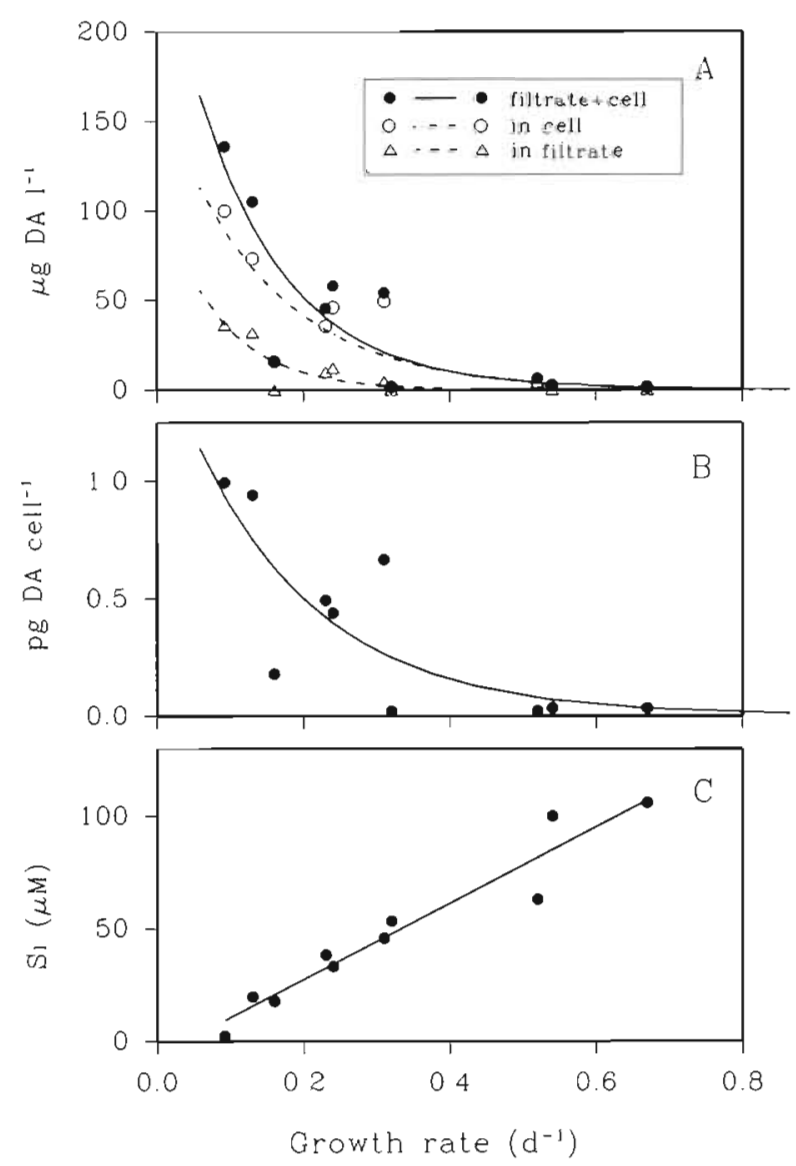

Fig. 3. Pseudo-nitzschla multiseries. Expt I. Relationships of (A) DA concentration, (B) cellular DA, and (C) DISi with growth rates. Inflow silicate concentration was $165.4( \pm 9.0) \mu \mathrm{M}$. Curves in $A$ and $B$ are fitted by Eq. (1). Line in $C$ is a linear regression

tion (1.354 pg cell-1 $\left.\mathrm{d}^{-1}\right)$ at $\mu=0.20 \mathrm{~d}^{-1}$ coincided with the highest C:Si (13.91) and C:P (125.6) ratios. This was associated with the highest particulate carbon $(771.4 \mu \mathrm{M})$ and chl a $\left(87.10 \mu \mathrm{g} \mathrm{l}^{-1}\right)$ in the culture.

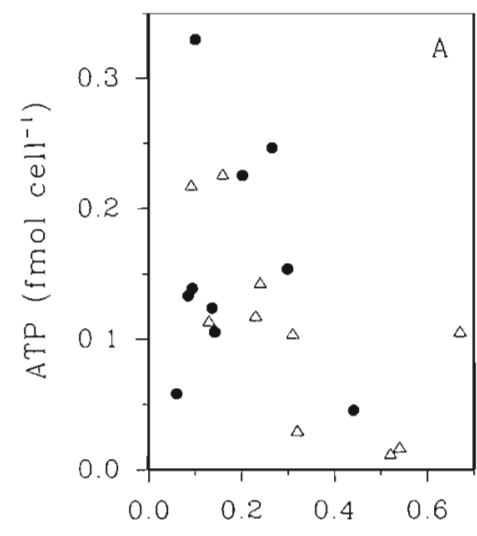

Growth rate $\left(\mathrm{d}^{-1}\right)$

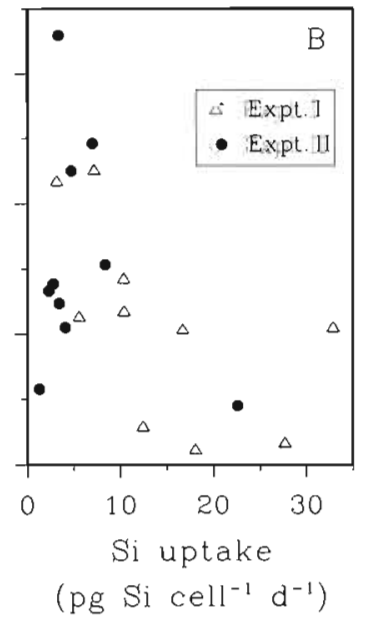

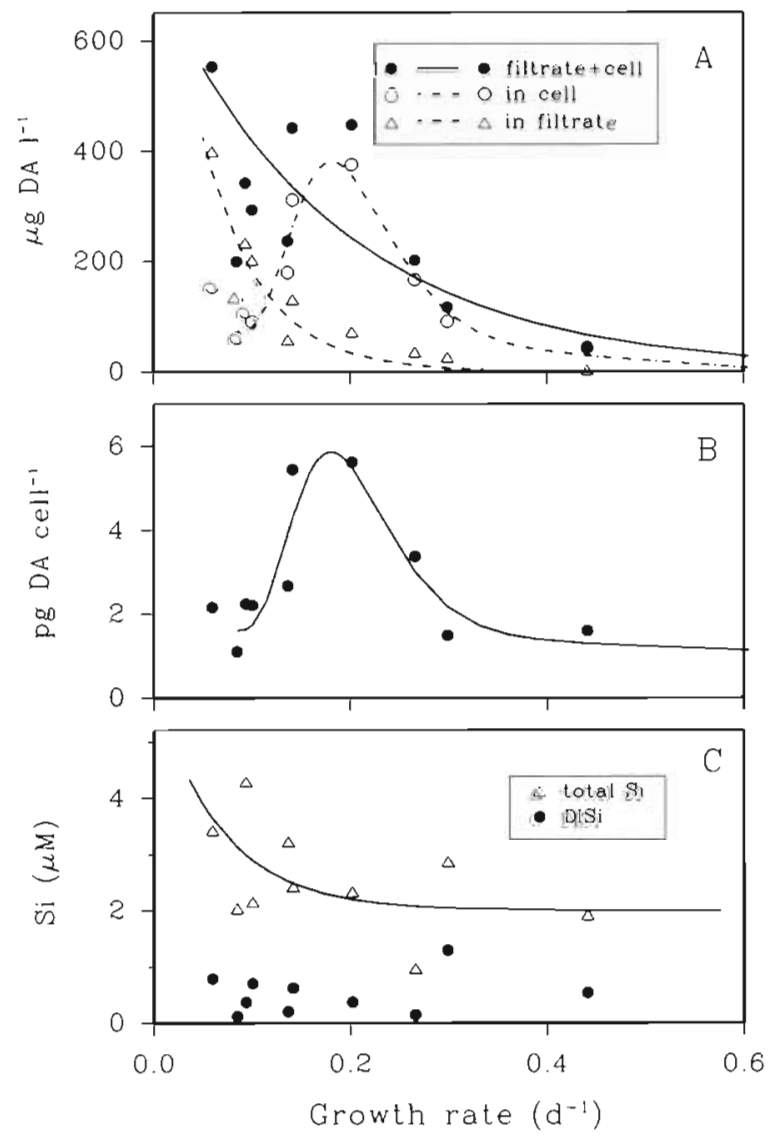

Fig. 4. Pseudo-nitzschia multiseries. Expt II. Relationships of (A) DA concentration, (B) cellular DA, and (C) DISi and total dissolved silicon with growth rates. Inflow silicate concentration was $56.2( \pm 3.4) \mu \mathrm{M}$. Curves are fitted by Eq. (1) or by eye

\section{Experiment III, batch mode (after continuous culture)}

After the addition of fresh medium was discontinued and the cultures were left as batch culture, the cell

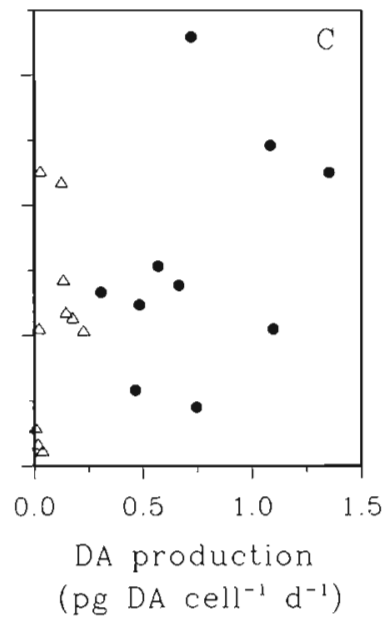

Fig. 5. Pseudo-nitzschia multiseries. Cellular ATP concentrations in relation to (A) growth rate, (B) silicate uptake, and (C) DA production 

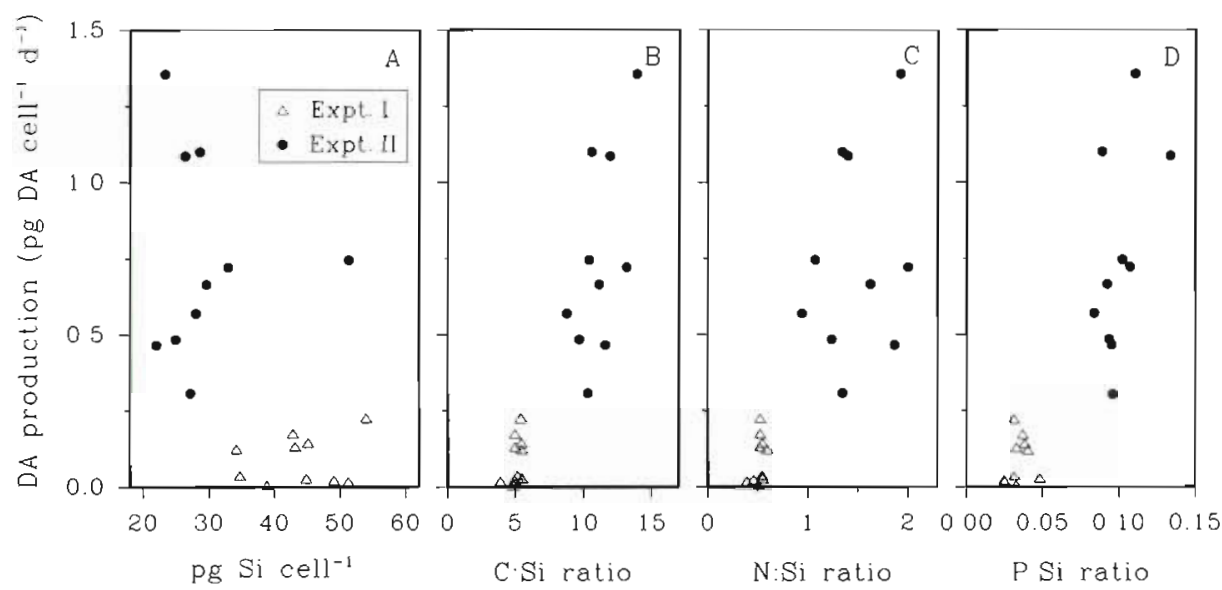

Fig. 6. Pseudo-nitzschia multiseries. Relationships between DA production and cell chemical composition

concentrations either increased or did not, depending on the growth rate of the previous steady state (Fig. 7A). For example, when the steady state growth
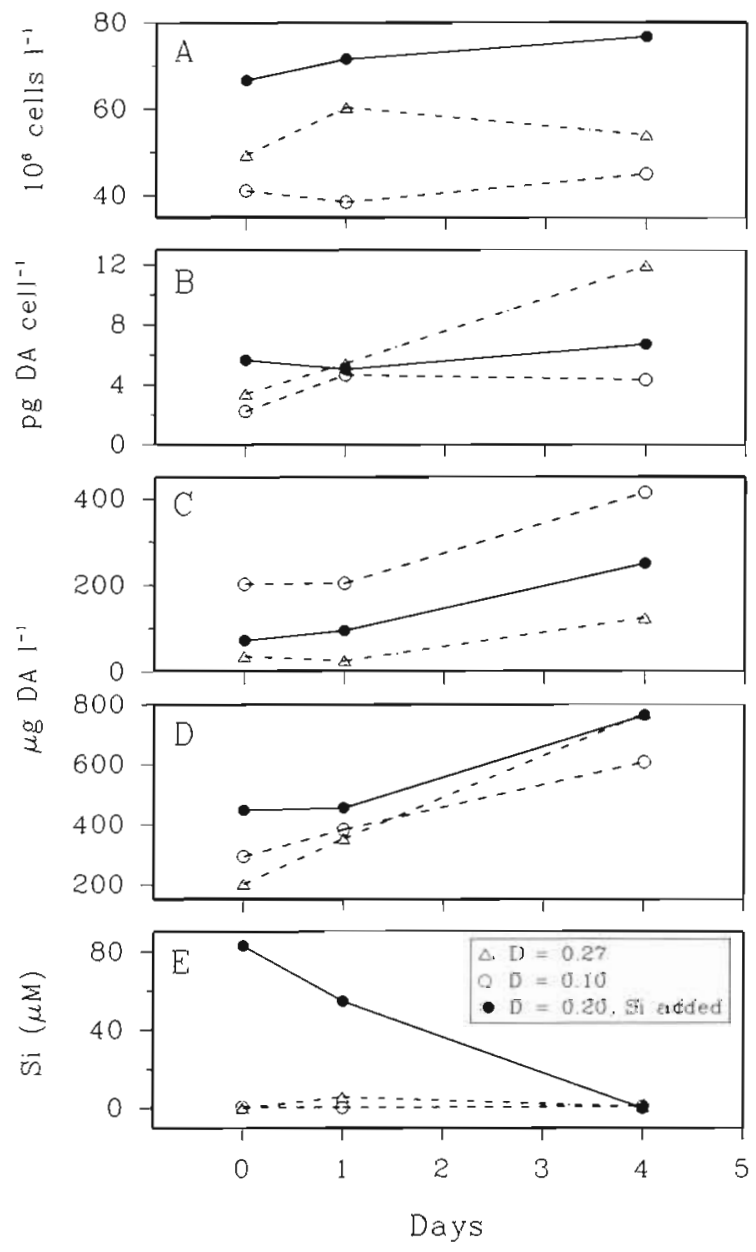

Fig. 7 Pseudo-nitzschia multiseries. Experiment III. Variations with time in (A) cell concentration, (B) DA in cell, (C) DA. in filtrate, (D) DA in cells + filtrate, and (E) DISi. Legends in $E$ are for all 5 panels; $D=$ dilution rates (growth rates) at steady states rate was $0.27 \mathrm{~d}^{-1}$, cell concentration increased from $49 \times 10^{6}$ to $60 \times 10^{6}$ cells $\mathrm{l}^{-1}$ in the first $21 \mathrm{~h}$. This increase $\left(\mu=0.265 \mathrm{~d}^{-1}\right)$ was comparable to the growth rate in the steady state. Further population growth was prevented by discontinuation of silicate supply essential for cell frustule formation. Production rate of DA was enhanced by a factor of 3 during the first $21 \mathrm{~h}$ after the curtailment of silicate supply (Table 3 ). Production continued at a slightly reduced rate during the following $3 \mathrm{~d}$. Total DA concentration at the end of the experiment was $768.5 \mu \mathrm{g} \mathrm{DA} \mathrm{^{-1 }}$, the highest ever reported for Pseudo-nitzschia multiseries. Of this, $644 \mu \mathrm{g} \mathrm{DA} \mathrm{l}{ }^{-1}$ occurred in the cells (11.9 pg DA cell ${ }^{-1}$ ) and $124.5 \mu \mathrm{g}$ DA $1^{-1}$ was in the filtrate. At a lower steady state growth rate $\left(0.10 \mathrm{~d}^{-1}\right)$ in another chamber, a 3 -fold increase in DA production rate was also evident during the first $21 \mathrm{~h}$ (Table 3 ). The production also continued at a slightly reduced rate during the following $3 \mathrm{~d}$.

In the third chamber, silicate $(85 \mu \mathrm{M})$ was added to the culture immediately after the steady state (Fig. 7) Cell concentration increased from 66.7 to $71.6 \times 10^{6}$ cells $\mathrm{l}^{-1}$ during the first $21 \mathrm{~h}$ and attained $76.7 \times 10^{6}$ cells $1^{-1} 3$ d later. On the other hand, no substantial increase of DA was found in this culture during the first $21 \mathrm{~h}$ (Table 3), but an increase during the following $3 \mathrm{~d}$ was evident because of the drastic decrease in silicate concentration (from 57.5 to $1.8 \mu \mathrm{M}$ ).

Table 3. Pseuda-nitzschia multiseries. DA production (pg cell ${ }^{-1} \mathrm{~d}^{-1}$ ) during steady state and batch modes

\begin{tabular}{|llccc}
\hline Chamber & & 1 & 2 & $3^{\text {a }}$ \\
\hline Steady state & Growth rate $\left(\mathrm{d}^{-1}\right)$ & 0.27 & 0.10 & 0.20 \\
& DA production & 1.09 & 0.72 & 1.35 \\
Batch modes & First 21 h & 3.17 & 2.60 & 0.12 \\
& Days 1 to 4 & 2.41 & 1.78 & 1.39 \\
\multirow{4}{*}{$85 \mu \mathrm{M}$ Si was added at the beginning of batch mode }
\end{tabular}




\section{DISCUSSION}

\section{Growth and Si uptake kinetics in relation to DA production}

Expts I and II differed in silicate concentration in the inflow medium, which resulted in significant difference in kinetics of growth and DA production. Growth rates of Pseudo-nitzschia multiseries in Expt I overlapped considerably with those in Expt II, while DA concentration in Expt I was markedly lower than in Expt II (Fig 2A). The population size of the culture was relatively constant in both experiments. In Expt I, grow th rate increased from 0.09 to $0.67 \mathrm{~d}^{-1}$ when residual silicate also increased from 2.4 to $106.2 \mu \mathrm{M}$. This suggests that (1) silicate was not the limiting factor in Expt I except when the growth rate was very low $\left(<0.09 \mathrm{~d}^{-1}\right.$, Fig 3C), (2) growth kinetics not only differed with growth rates but also with various concentrations of inflow substrate, i.e. the supply rate of silicate, and (3) at the same growth rate, cells produced more DA under silicate stress.

In Expt I, although there was sufficient silicate for further growth of the population, it never reached more than $1.05 \times 10^{8}$ cells $1^{-1}$, which was comparable to our earlier data from batch culture experiments (Pan et al. 1991, 1996). Light was not limiting because the population grew well at much lower light intensities (Pan et al. 1991). Other nutrients such as nitrogen, phosphorus and vitamins were in excess. The population size was probably restricted by some intrinsic physiological mechanism. This is in agreement with our observation on late exponential phase of batch cultures (Pan et al. 1996). The first stage DA production in batch cultures may be initiated when this intrinsic restriction is effective.

In Expt II, on the other hand, there was clear evidence of silicate limitation. The average silicate uptake rate was lower, and the silicate content per cell was lower (Table 1 ; Figs. 2 \& 6). At the same time, DA production was much higher.

The differences in mechanism and magnitude of DA production in continuous culture between Expts I and II paralleled the differences between the first and second stages of DA production in batch cultures (Table 4). This parallelism suggests the existence of 2 types of conditions associated with DA production (Table 5). Type I, which is essential to DA production, is related to decline of overall physiological activity when DISi is moderately low; in Type II, the population growth is completely arrested by severe DISi limitation.

At very low growth rates in Expt II $\left(\mu<0.14 \mathrm{~d}^{-1}\right)$, total silicon in the medium increased when the growth rate decreased (Fig. 4C), suggesting dissolution of silicon
Table 4. Pseudo-nitzschia multiseries. Comparison of DA production at steady state with that in the batch cultures under silıcate limitation. $\mu_{m i}$ : maximum growth rate

\begin{tabular}{|lll|}
\hline DA production & Batch culture & Continuous culture \\
\hline No & $\begin{array}{l}\text { Early exponential } \\
\text { phase }\end{array}$ & Approaching $\mu_{\mathrm{m}}$ \\
Low & $\begin{array}{l}\text { Late exponential } \\
\text { phase (first stage) }\end{array}$ & $\begin{array}{l}\text { High silicate supply } \\
\text { (Expt I) }\end{array}$ \\
High & $\begin{array}{l}\text { Stationary phase } \\
\text { (second stage) }\end{array}$ & $\begin{array}{l}\text { Low silicate supply } \\
\text { (Expt II) }\end{array}$ \\
\hline
\end{tabular}

Table 5. Pseudo-nitzschia multiseries. Characterıstics of 2 types of conditions for DA production

\begin{tabular}{|lll|}
\hline Characteristics & Type I & Type II \\
\hline DA production rate & Low & High \\
Nutrient concentration & Low & Depleted \\
Cell division & Yes & Yes or No \\
Inducing factor(s) & Intrinsic & Extrinsic \\
Examples & & \\
Batch cultures & First stage & Second stage \\
Continuous cultures & Expt 1 & Expt Il \\
\hline
\end{tabular}

from the cell walls. Simultaneously, DA was released from cells into the medium (Fig. 4A), suggesting that cells retain less DA under critical stress. This result is in agreement with the decline of DA content in the cell in the senescent phase of batch culture of the same species (Subba Rao et al. 1990, Bates et al. 1991, Pan et al. 1996). This may be because the critical silicate stress not only weakened the cell frustules (as in $\mathrm{Nav}$ icula pelliculosa, Lewin 1957) but also restrained DA production and impaired the integrity of the cell membrane. Very likely, DA, a small-molecular watersoluble compound, is transported passively through the membranes. Otherwise, when cells are not severely stressed, the membrane probably limits this transport and retains most DA in the cells.

There was a surge in DA production following transfer of the culture from steady state to batch mode (Table 3) when the supply of silicate stopped (Fig. 7). But the production later declined slightly. Following the addition of silicate to the culture, on the other hand, there was a surge in silicate uptake las has been found in Skeletonema costatum; Conway et al. 1976) but DA production was suspended. At the steady state, DA production was significant when growth was low. This phenomenon fits the general pattern of secondary metabolism well (Vining 1986). At high growth, primary metabolism such as uptake and allocation of various nutrients and synthesis of cell constituents are very active, which establishes a 
higher demand for metabolic energy and results in less free energy in the form of ATP. For example, reduction of ATP at a high Si uptake rate and in fastgrowing populations suggests a high energy consumption (Fig. 5). In these populations, DA production could have been partly inhibited because of the deficiency of free energy (Pan 1994).

\section{Ecological perspectives}

DA episodes recurred in the bays around Prince Edward Island in late fall and winter from 1987 to 1991. Silicate concentration was much lower in natural sea water than in the culture, but DA levels were generally higher. Our culture experiments show that cells produce more DA under lower supplies of silicate even at the same growth rate. It is very likely that the natural blooms of Pseudo-nitzschia multiseries were severely silicate stressed and therefore produced more DA.

Usually, a harmful algal bloom is preceded by a diatom bloom. The bloom of Pseudo-nitzschia multiseries in fall 1988 in Cardigan Bay was preceded by a bloom of Skeletonema costatum (Smith et al. 1990). A bloom of diatoms in spring followed by a bloom of flagellates or dinoflagellates in summer is a normal event in temperate marine habitats (Smayda 1980, Cushing 1989, Mann 1993). For example, Silva (1985) found that the Prorocentrum minimum bloom in the Obidos Lagoon (Portugal) was preceded by blooms of S. costatum. Maestrini \& Granéli (1991) attributed a 1988 Chrysochromulina polylepis bloom in Scandinavian coastal waters to preceding diatom blooms. The bloom diatoms reduce the reservoir of silicate by settling to the bottom and subsequently alter the ratios of $\mathrm{N}: \mathrm{Si}, \mathrm{P}: \mathrm{Si}$ in lakes, coastal waters and inland seas (Conley et al. 1993). These altered nutrient ratios lead to a succession of phytoplankton, in which species that are more competitive in low-silicate environments are favoured.

A preceding bloom of another diatom or a prolonged bloom of Pseudo-nitzschia multiseries depleted the silicate in the sea water and resulted in enhancement of DA production. When the toxigenic bloom of $P$. multiseries was at its height in Cardigan Bay on December 16,1987 , silicate concentration was as low as $0.62 \mu \mathrm{M}$ (Subba Rao et al. 1988). DA poisoning peaked $10 \mathrm{~d}$ later (Smith et al. 1990, Silvert \& Subba Rao 1992). This time scale is in agreement with the results of the present study. In the cultures, soon after transition from steady states to batch mode, DA production was greatly enhanced whether the culture population increased or not. At the peak of the bloom, depletion of DISi led to Type II conditions and promoted DA production.
Acknowledgements. We are grateful to Dis D. C. Gordon Jr, J. E. Stewart and G. C. Harding and 3 anonymous reviewers for constructive criticism of the manuscript. We thank Dr R. Pocklington and his associates, who analyzed all the domoic acid samples. Y.P. was supported by a research grant from the Natural Sciences and Engineering Research Council of Canada (NSERC) to Dr K. H. Mann.

\section{LITERATURE CITED}

Addison RF, Stewart JE (1989) Domoic acid and the eastern Canadian molluscan shellfish industry. Aquaculture 77 : 263-269

Bates SS, de Freitas ASW, Milley JE, Pocklington R, Quilliam MA, Smith JC, Worms J (1991) Controls on domoic acid production by the diatom Nitzschia pungens $\mathrm{f}$. multiseries in culture: nutrients and irradiance. Can J Fish Aquat Sci 48:1136-1144

Conley DL, Schelske CL, Stoermer EF (1993) Modification of the biogeochemical cycle of silica with eutrophication. Mar Ecol Prog Ser 101:179-192

Conway HL, Harrison PJ, Davis CO (1976) Marine diatoms grown in chemostats under silicate or ammonium limitation. Il. Transient response of Skeletonema costatum to a single addition of limited nutrient. Mar Biol 35:187-199

Cushing DH (1989) A difference in structure between ecosystems in strongly stratified waters and in those that are only weakly stratified. J Plankton Res 11:1-13

FTR Software (1991) FITALL - nonlinear regression analysis (research edition). FTR software, Toronto

Humphrey GF (1963) Chlorophyll $a$ and $c$ in cultures of marine algae. Aust J mar Freshwat Res 14:148-154

Karl DM, Holm-Hansen O (1980) ATP, ADP, and AMP determinations in water samples and algal cultures. In: Hellebust JA, Cragie JS \{eds\} Handbook of phycological methods, physiological and biological methods. Cambridge University Press, London, p 197-206

Koroleff F (1983a) Determination of silicon. In: Grasshoff $\mathrm{K}$, Ehrhardt E, Kremling KK (eds) Methods of seawater analysis. Verlag Chemie, Weinheim, p 174-183

Koroleff F (1983b) Determination of phosphorus. In: Grasshoff K, Ehrhardt E, Kremling KK (eds) Methods of seawater analysis. Verlag Chemie, Weinheim, p 125-139

Lewin JC (1957) Silicon metabolism in diatoms. IV. Growth and frustule formation in Navicula pelliculosa. Can J Microbiol 3:427-433

Maestrini SY, Granéli E (1991) Environmental conditions and ecophysiological mechanisms which led to the 1988 Chrysochromulina polylepis bloom: an hypothesis Oceanol Acta 14:397-413

Mann KH (1993) Physical oceanography, food chains, and fish stocks: a review. ICES J mar Sci 50:105-119

Pan Y (1994) Production of domoic acid, a neurotoxin, by the diatom Pseudonitzschia pungens f. multiseries Hasle under phosphate and silicate limitation. PhD thesis, Dalhousie University

Pan Y, Subba Rao DV, Mann KH, Brown RG, Pocklington R (1996) Effects of silicate limitation on production of domoic acid, a neurotoxin, by the diatom Pseudo-nitzschia multiseries. I. Batch culture studies. Mar Ecol Prog Ser 131: $225-233$

Pan Y, Subba Rao DV, Warnock RE (1991) Photosynthesis and growth of Nitzschia pungens f. multuseries Hasle, a neurotoxin producing diatom. J exp mar Biol Ecol 154 77-96

Pocklington R, Milley JE, Bates SS, Bird CJ, de Freitas ASW, 
Quilliam MA (1990) Trace determination of domoic acid in seawater and phytoplankton by high-performance liquid chromatography of the fluorenylmethoxycarbonyl (FMOC) derivative. Int J Environ Analyt Chem 38:351-368

Silva ES (1985) Ecological factors related to Prorocentrum minimum blooms in Obidos Lagoon (Portugal). In: Anderson DM, White A, Baden DG (eds) Toxic dinoflagellates. Elsevier, New York, p 251-256

Silvert W, Subba Rao DV (1992) Dynamic model of the flux of domoic acid, a neurotoxin, through a Mytilus edulis population. Can J Fish Aquat Sci 49:400-405

Smayda TJ (1980) Phytoplankton species succession. In: Morris I (ed) The physiological ecology of phytoplankton. University of California Press, Berkeley, p 493-570

Smith JC, Cormier R, Worms J, Bird CJ, Qulliam MA, Pocklington R, Angus R, Hanic L (1990) Toxic blooms of the domoic acid containing diatom Nitzschia pungens in the

This article was submitted to the editor
Cardigan River, Prince Edward Island, in 1988. In: Granéli E, Sundström B, Edler L, Anderson DM (eds) Toxic marine phytoplankton. Elsevier, New York, p 227-232

Strickland JDH, Parsons TR (1972) A practical handbook of seawater analysis. Fish Res Bd Can Bull 167

Subba Rao DV, de Freitas ASW, Quilliam MA, Pocklington R, Bates SS (1990) Rates of production of domoic acid, a neurotoxic amino acid in the pennate marine diatom Nitzschia pungens. In: Granéli E, Sundström B, Edler L, Anderson DM (eds) Toxic marine phytoplankton. Elsevier, New York, p 413-417

Subba Rao DV, Dickie PM, Vass P (1988) Toxic phytoplankton blooms in the eastern Canadian Atlantic embayments. Comm Meet Int Coun Explor Sea, C.M. ICES 1988/L:28

Vining L (1986) Secondary metabolism. In: Rehm HJ, Reed G (eds) Biotechnology, Vol. 4. VCH Verlagsgesellschaft, Weinheim, p 19-38

Manuscript first received: April 19, 1995

Revised version accepted: July 18, 1995 